inwards. It might be worth while to construct a light wooden framing that would cover one of the smaller walls of the National Gallery, to hang upon it pictures with dark backgrounds and then to tilt the screen forwards and note the improvement in visibility under the conditions of top lighting in use there.

\section{Museum Improvements}

Two articles of real value to museum curators appear in the Museums Journal for September. The first, by Dr. L. J. Spencer, discusses the artificial lighting of museum cases, and recommends the use of strip lights along the upper portion of the case, and the painting out of shadows cast by solid shelves. The assumption in such a case is that ordinary daylight lighting is ignored. Diagrams illustrate some of the cases of minerals in the British Museum lit by the method described, one tall (10 ft.) case showing a specially neat method of making use of the otherwise useless upper portion, by the fitting of transparent pictures illuminated from behind. In a second article, Mrs. Jean C. Stevens suggests a way of replacing the very expensive jointed figures used (where they can be afforded) for the display of costumes. With a little ingenuity effective figures can be made at a small cost, with cylinders of rabbit netting. The cylinders, head, arms, body, etc., can be 'bent' into shape as desired, and in proper position can be supported by strengthening struts of wire or wood. If the illustrations represent the results of this process, the home-made figures should find a comfortable home in many a museum, impoverished or otherwise.

\section{British Commercial Gas Association}

THE British Commercial Gas Association, founded for co-operative publicity effort in the gas industry, held its coming-of-age meeting in Leeds during the past week. Prince George, after seeing something of the manufacture of gas and gas appliances in the city, attended the dinner on Tuesday evening and gave an interesting review of the achievements of the industry. Major Geoffrey Kitson, in his presidential address, set forth further particulars of the present conditions, stating among other things that there are now five million 'slot consumers' on the books of the industry ; that $£ 180,000,000$ of money and a yearly consumption of $18,000,000$ tons of coal, are involved; and that 100,000 workmen are employed. He alluded to the advances being made in new directions, and in the afternoon, Mr. A. W. Smith, general manager and secretary of the Birmingham Gas Department, stated in his paper that authority has been obtained from the Home Office to run a test vehicle on the road with special steel cylinders containing gas at a pressure of $3000 \mathrm{lb}$. a square inch. It is hoped that gas so supplied may also be used for country houses and farms in districts remote from gas mains.

The executive chairman, Sir Francis Goodenough, at the opening of the Conference, spoke of the difficult days sure to follow upon the completion of the electricity grid, controlled by the Central Electricity Board. He foresees a desperate effort to get business for the grid "backed up more and more from Whitehall". It was in the gas industry that Sir Francis gained his first laurels as an authority on salesmanship and he insisted on the importance of perfecting the commercial side and of practising individual as well as collective enterprise. Major Kitson, who is chairman of the Leeds City Gas Department, urged the importance of gas and electricity, by co-partnership and concentration, setting themselves at once to achieve a national ideal of service in the most economical extraction of the potential heat, light and power from the great reservoir of energy-our sole native source-the coal fields. If the spirit and demeanour exhibited by Major Kitson prevailed more generally it would be a matter for congratulation. Extravagant ex parte statements by the advocates of the two agencies where their services overlap are greatly to be deplored, and they appear to be increasing. Among other things it is to be remembered that the exact measurement of the efficiency of heating appliances is still a subject of difficult scientific investigation. It is appropriate to say that in this and other technical problems, the University in the city where the Conference was held has long co-operated in a fruitful way with the Institution of Gas Engineers and that it has a chair of coal gas and fuel industries founded as a memorial to a great gas engineer, the late Sir George Livesey. In this and one or two other university centres in Great Britain, the scientific education of the gas engineer is now seriously taken in hand and is producing a long-needed type of recruit.

International Scientific Investigation of Population Problems

THE first World Population Conference was held under the auspices of the International Union at Geneva in 1928 and the second Conference at London in 1931. The proceedings of these Conferences have been published. In addition, three standing committees organise and to some extent subsidise research (The International Union for the Scientific Investigation of Population Problems : its Foundation, Work, Statutes and Regulations. Pp. 28. London: c/o Royal Geographical Society, 1932). It might perhaps be a matter for debate whether the results so far published justify a new and cumbrous organisation. But it is another matter when we take into account the value of an attempt to look at population problems from an intermational angle. All population problems have two aspects-a domestic and an international. The problem of emigration is a case in point. It may be that too much importance has been sometimes attributed to population movements, when, for example, war has been traced to over-population. But there can be no doubt that in many subtle ways population movements do affect international relations very profoundly. Thus if the Union can keep international aspects to the front, it will be justified whatever may be the value of the research which it directly advances. It may perhaps be said that in the long run the successful

No. 3284, Vol. 130] 